\title{
A Late Nineteenth Century Muslim Response to the Western Criticism of Islam-An Analysis of Amir 'Ali's Life and Works
}

\author{
Abdullah Ahsan*
}

There were more than one scholar in the nineteenth century Muslim world working for the development of the community through their writings and political activities. Justice Sayyid Amir 'Ali was one of them in the Indian sphere of Islam. This article attempts to determine 'Ali's position within the development of Muslim community in India. Our aim is to examine ${ }^{c}$ Ali's views of Islam critically in order to find out the values he aimed at. We are not concerned with giving our views of Islam on the issues 'Ali dealt with, but rather we will try to determine how his interpretation of Islam contributed to the development of Muslims in India.

The wave of modernity in the Indian sub-continent, in the sense of western technological development and philosophical ideas, was caused by British imperialism in the nineteenth century. ${ }^{1}$ Christian missionary activities also played a remarkable role in achieving this goal. ${ }^{2}$ The Muslims of India, however, considered the Christian missionary attitude of identifying western material development with Christianity as a challenge that was reflected through the intellectual activities of Muslim scholars. Their response was an attempt to absorb, transform, reject or adjust their belief system to the forces of moder-

\footnotetext{
* Dr. Abdullah Ahsan is completing a book on the origins and development of the organization of The Islamic Conference. He obtained his doctorate from the University of Michigan at Ann Arbor, Michigan, USA.

' W.C. Smith, Modern Islam in India. (London: Victor Gollancz, 1946) p. 11

${ }^{2}$ D.C. Sen, History of Bengali Language and Literature. (Calcutta: University of Calcutta, 1954) p. 717
} 
nity. Amir ${ }^{C}$ Ali was pursuaded to write on Islam by an American scholar. ${ }^{3}$ Later he discovered that the knowledge of Islam in the west was, to a great extent, biased. ${ }^{4}$ Particularly after reading Sir William Muir's Life of Mahomet, Ali felt that the book "requires a refutation of every false theory stated in it."

An academic approach to the study of Islam in the west began in the beginning of the modern period. ${ }^{6}$ This approach received a substantial boost with the contribution of Sir William Muir, one-time governor of the North-Western Provinces of India. He was probably the first biographer of the Prophet of Islam who had an access to the original sources on the subject. Because of his access to these source materials and his adoption of a critical approach to these sources, he is considered the father of critical scholarship on Islam in the west. Even many modern Muslim scholars consider him an authority on many issues regarding the Prophet's life and contribution. ${ }^{7}$ But he was not free from medieval European notion ${ }^{8}$ of a Muslim being "always armed with sword in one hand and the Qurān in the other." ${ }^{\text {"M }}$ Muir's contribution to Islamic scholarship and his pre-conceived notion can be summed up in the statement of Leonard Binder, who says, "Aside from the implicit anti-Islamic prejudice in his work, all students of the Middle East are deeply indebted to Muir. ..."10 J. Richter, author of $A$ History of Missions in India, notes about Muir's contribution that:

${ }^{3}$ A. 'Ali, "Memoirs," Memoirs and Other Writings of Ameer Ali. ed R. Wasti. (Lahore: People's Publishing House, 1968) pp. 32-33.

4. . "The Mohammedans of India and their Place in the Empire," Ameer Ali: His Life and Work. ed. K.K. Aziz. (Lahore: Publishers United 1968) p. 378.

5. . "A Critical Examination of the Life and Teachings of Mohammed. (London: William and Norgate, 1873) Preface, pl. vii.

${ }^{6}$ Norman Daniel, Islam and the West: Making of an Image. (Edinburgh: Edinburgh University Press, 1958) p. 294.

7 Hussain Haykel, for instance, considers Muir an authority on the use of the Qur'an as a source of the Prophet's life. cf. M.H. Haykel The Life of Muhammad. Eng. Tr. of Hayate-Muhammadi, tr. I. Faruqi (Indianapolis: North American Trust Publications, 1976) pp. Ixiii-Ixx.

${ }^{8}$ The mediaval notion of Islam in the west was as Southern puts it:

“. . a large number of enemies threatening Chrestendom from every direction, and they had no interest in distinguishing the primitive idolatries of Northmen, Slavs, Magyers from the monotheism to Islam, or the Manichaean heresy from that of Mahomet.

(R. W. Southern, Western Views of Islam in the Middle ages, Cambridge Harvard University Press, 1962, p. 3)

${ }^{9}$ Peter Hardy, The Muslims of British India. (Cambridge: Cambridge University Press, 1972) p. 62.

${ }^{10}$ Leonard Binder, The Idiological Revolution in the Middle East. (New York: John Willey \& Sons, Inc. 1964) p. 47. 
To provide missionaries with weapons in their difficult spiritual warfare with Islam, Sir William Muir, the learned and pious ruler of NW provinces and later principal of Edinburgh University, wrote a 'Life of Mahomet' in four volumes."

Whatever may be the reason behind Muir's initiative to write on Islam, his contribution is a substantial one in the development of critical scholarship on Islam.

Muir emphasized several issues, including the Prophet's family life, his treatment of Madinian Jews, status of women in Islam, the spread of Islam through the non-Arab lands, Islam and slavery and the use of reason in Islam. Amir 'Ali found Muir's treatment of these issues full of anit-Muslim sentiments. Consequently 'Ali in his own works on Islam treated the same issues at length and defended, in most cases, the traditional Muslim view points. Amir ${ }^{\mathrm{C}} \mathrm{Ali}$ entered into a direct controversy on several issues on Islam at a later date with a few British writers, but he maintained similar views throughout on those issues. ${ }^{12}$

Amir Ali directly challenges few of Muir's theories which the former considers as false theories. Muir attacks the Prophet's character at Madina as saying, "Battles were fought, executions ordered and territories annexed under the cover of Almighty sanction."13 To begin with his treatment of this issue Amir ${ }^{c}$ Ali says that:

By their (Jews) superior education and intelligence, by their union with the party of the Munäfikin, and by general unanimity which prevailed among them, the Jews formed a most dangerous element within the federated state which had risen under the teacher of Islam. . 14

On the issues of the Prophet's treatment of the Madinian Jews it appears that Muir is selective in choosing his sources. He cites stories about relations between the Muslims and the Jews but gives one side of the picture, and does not take into account the provision of their mutual oaths against outside enemies. Muir says:

... shortly after his (the Prophet's) return from Badr; and having

" Joseph Scaff, "Christian Missionary Attitude Towards Islam in India." (Unpublished M.A. Thesis, Montreal: McGill University, 1981) p. 109.

${ }^{12}$ A. Ahsan, "Muslim Response to the Western Criticism of Islam: A Study of Amir Alis Life and Works," (Unpublished M.A. Thesis Montreal: McGill University, 1981) pp. 33-53.

${ }^{13}$ William Muir, Life of Mohammad. New revised Edition. (Edinburgh: John Grant, 1912) p. 520 .

14 A. 'Ali, The Spirit of Islam. Reprinted from 1922 ed. (Karachi: Pak Publishers Ltd. 1969) p. 72 . 
assembled the chief men, summoned them to acknowledge him as their Prophet. 'By the Lord' he said, 'ye know full well that I am the apostle of God. Believe, therefore, before that happen to you which has befallen Koreish! They refused, and defied him tọ do his worst. ${ }^{15}$

Historically this is not ture. The way events went with the Jews and their relations with the Muslims are well depicted in the sources which Muir uses, and using more or less the same source materials 'Ali gives the Muslim version of the story. He discusses the Jewish behaviour after the Muslim victory at Badr and the acts of a Jewish poet inciting people against the confederation of Madina in favour of the Makkans.1\% It was at this extreme stage, as 'Ali understands it, that severe action was taken by Muhammad (ȘAAS). 'Ali tries to justify the severity of the Prophet's action by quoting parallel examples from other people's histories. He quotes from Arnold's Sermons (War of Israelites, pp. 35-36) that:

It is better that the wicked should be destroyed a hundred times over than that they should tempt those who are yet innocent to join their company. ${ }^{17}$

He again quotes from Grote's History of Greece as saying that the type of punishment the Prophet gave to the Jews was in accordance with the laws of war of those days. ${ }^{18}$ CAli quotes Lane Poole to support his views about the Prophet's treatment of the Jews. He attacks Muir, Sprenger, Weil, and Osborn for being prejudiced and presenting a biased picture of the story. ${ }^{19}$ At the same time he says:

I can only remember M. Barthelemy St. Hilarie, Mr. Johnson, and $\mathrm{Mr}$. Stanley Lane Poole among Europeans who have not been carried away by prejudice. ${ }^{20}$

${ }^{\mathrm{c}}$ Ali does not disagree with Muir about the fact of the severiety of the treatment met by the Jews. He merely justifies such treatment by saying:

This was a severe punishment according to our ideas, but it was customary according to the rules of war then prevalent. ${ }^{21}$

Thus reflecting Grote's views he manifests his lack of confidence in dealing

\footnotetext{
15 Muir, p. 241.

$16^{\circ}$ Ali, SI, pp. $73 \mathrm{ff}$.

17 Ibid. p. 81.

18 Ibid.

19 Ibid.

${ }^{20} \mathrm{Ibid}$. p. $81 \mathrm{n}$.

21 "Ali, A Short History of the Saracens. Revised ed. (London: MacMillan, 195I) p. 14.
} 
with the actions of the Prophet. He is not only defensive about Islam but also launches a counter attack on others, particularly on Christians and the Christian biographers of the Prophet. He refers always to 'Christian controversialists' when attacking the European scholars of Islam. ${ }^{22}$ This generalised statement contradicts his own position when he quotes western scholars when it suits his views. 'Ali considers Muir as an enemy of Islam, yet he quotes Muir when the latter praises Islam. ${ }^{23} \mathrm{He}$ qualifies his quotations from Muir by saying that it was an unconscious thrill on the part of Muir.

${ }^{\mathrm{c}}$ Ali treats other issues similarly. ${ }^{24} \mathrm{He}$ not only defends Islamic concepts against accusations of Muir and other western historians, he frequently identifies Islamic concepts with the demands of various social movements in the late nineteenth century England. He boasts of the fact that Islam provided women with the right of possessing property without the intervention of their fathers or husbands in the seventh century while in English Common Law the right was not recognized until $1882 .{ }^{25}$ Women's rights were neglected or ignored in every culture before Islam, and the situation improved substantially by the Islamic accordance of women's property and other rights. ${ }^{26} \mathrm{He}$ goes on to review the history of Islam in order to point out positions Muslim women attained, and quoting the example of Räbicah (a saint lady of the second century of Islam) he makes a sweeping statement about Islamic history that Islam produced thousands of women like Rabi'ah. This statement did not pass by without notice by modern scholars. Gibb, for example, challenges this statement of ${ }^{C} \mathrm{Ali} .{ }^{27}{ }^{\mathrm{C}} \mathrm{Ali}$ was closely associated with Millicent Fawcett, a leader of the women's suffrage movement in England. ${ }^{28}$ In many of the demands of this movement, he discovered a similarity with the Islamic recognition of women's rights. It appears that this made him proud of his identity, and this pride led him to make exaggerated claims.

'Ali pointed only to the glories of Islam and exaggerated his claims. This gave rather a 'romatic view' of Islamic history, which apparently affected the later generation adversely. Sayyid Ahmad Khan, founder of the famous Aligarh School in India, had adopted a critical attitude towards Islamic history, and later Shibli Nu'mäni, another famous historian of the same school, developed this cause. ${ }^{29}$ Like Amir ${ }^{c} \mathrm{Ali}$, Shibli $\mathrm{Nu}^{c}$ manni also reacted against western
${ }_{22}^{2}$ Ali, SI. p. 82 .
${ }^{23}$ Ibid. pp. 43 \& 94.
24 Ahsan, pp. 35-54.
${ }_{25}^{\circ}$ Ali, DI, p. 256.
26 Ibid. pp. 246-247.
${ }^{27}$ H.A.R. Gibb, Modern Trends in Islam. (Chicago: Chicago University Press, 1950) p. 59.
28 'Ali, "Memoirs," p. 17.
${ }^{29}$ Aziz Ahmad, Islamic Modermism in India and Pakistan. (Oxford: Oxford University Press, 1967) pp. $77-86$. 
scholarship on Islam and in order to face the western challenge in this respect he adopted a critical view of Islamic history. The latter, therefore, was not ready to accept every story mentioned in the earliest Sirah literature, as he did not rely upon European works on Islamic history. On the other hand, Amir 'Ali took the stand of defending almost everything in Islamic history. This discouraged later Muslims to study their past critically, which in turn exerted an adverse affect on their intellectual orientation. Shibli Nu'mani did not hesitate to emphasize facts and opinions unfavourable to 'Umar, the second caliph of Islam. ${ }^{30} \mathrm{He}$ commended the orientalists' initiative in collecting and editing manuscripts of old Islamic works, their efforts to establish 'a historical and scientific perspective for the study of Islam' and the project of the Encyclopedia of Islam. This attitude is not found in Amir 'Ali's works.

'Ali is proud of his identity. He boasts of the fact of a woman being the education minister in Turkey. ${ }^{32}$ But he is not comfortable with the Islamic injunctions about the seclusion of women. He thinks that it is necessary only in unsettled and uncultured communities, and thus he wants to reform modern Muslim society in this respect. ${ }^{33} \mathrm{He}$ does not realize that by so demanding he was belittling the status of the Prophet's society which he always wanted to glorify. He forgets that such a claim is against the spirit of another claim of his, namely, the universality of the Qur'ann.

W.C. Smith rightly observes that Amir 'Ali focuses Islam as a superior religion to Christianity. ${ }^{34}$ This sense of superiority, 'Ali says, 'Islam' bears in its name. Unlike Christianity, which derives from the designation of Jesus as Christ, there is a significance in the word 'Islam.' The word, according to 'Ali, means to be tranquil, to be at perfect peace which comes about through obedience to God. ${ }^{35}$ In every aspect of his discussion, he compares the existence of the relevant institution in both civilizations. He always tries to focus on the greatness of Islam over Christianity. This comparison, however, is not unique to 'Ali's scholarship. Many western scholars such as Muir and others compared Islam and Christianity before 'Ali. The basic difference between 'Ali and the western scholars in this respect is that while the former focused on the superiority of Islam, the latters focused on the superiority of Christianity.

'Ali thinks that there is no difference between Islam and Christianity in their essence, but that Christianity lost its spirit with the influence of Paul upon it. ${ }^{36}$ This of course not a new notion in Islam. The Qur'an itself declares

\footnotetext{
${ }^{30}$ Ibid. p. 81 .

${ }^{31}$ Ibid. pp. 81-85.

${ }_{32}$ "Ali. "The Caliphate and the Islamic Renaissance," Life and Works. p. 440.

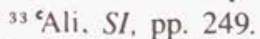

34 Smith, p. 12.

${ }^{35}$ 'Ali, SI, p. 137.

${ }^{36}$ Ibid, p. 180.
} 
that the Christians were given guidance, but they had broken their covenant with God (V:14), and denies that the Christians follow their prophets; rather the Muslims were the true followers of Abraham (11:135), and Islam, in fact, is the true religion (11:120). A special characteristic of Amir 'Ali in this respect is that he goes on to the history of the Christian people and points to particular events in order to support his polemics against the Christian religious tradition. But the problem with his dealings with history is that in most cases he does not document the charges he brings against Christianity. For example, when comparing Christianity with Islam in respect of tolerance, he says:

In the seventeenth century a young man was hanged for having said, it is stated, that he did not think Mohammed was a bad man. ${ }^{37}$

but he does not support his statement by giving reference to his source.

One of Amir 'Ali's main concern is the use of reason in Islam, since he knows that the use of reason was a chief factor in the development of science and technology in the west. Muir, on the other hand, challenges the idea that Islam allows rational enquiry, ${ }^{38}$ and argues that it believes in miracles and superstitions. ${ }^{39}$ In response to Muir, 'Ali says that Islam not only allows the use of reason, but unlike Christianity it encourages the use of reason. $\mathrm{He}$ argues that Islamic teachings are based on rationalism and are close to European liberal thought. ${ }^{40} \mathrm{He}$ refers to various Quränic verses which urge a human consciousness of the order in nature and assert the existence of One Supreme Being.

${ }^{c}$ Ali claims the Prophet of Islam never travelled out of the province of reason. ${ }^{41}$ Therefore, he gave an allegorical interpretation to those concepts of Islam which appeared to him as being contradictory to science in the light of late nineteenth century discoveries. According to him the idea of continued life beyond the grave "must have been developed from the yet unconscious longing human soul for a more extended sphere, where the separation of dear friends, so painful to both savage and civilized man, should end in reunion."42 $\mathrm{He}$ discusses Islamic doctrines and differentiates between those which were floating around in pre-Islamic Arab society and those introduced by Islam. According to him, Islam adopts the concept of paradise from Zoroastrianism and the concept of hell from Talmud. Then he discusses the description of heaven and hell in Islam and says that the Prophet had to interpret spiritual

\footnotetext{
${ }^{37}$ Ibid. $218 \mathrm{n}$.

${ }^{38}$ Muir, preface, p. Ixiv.

${ }^{39}$ Ibid.

$40^{\circ} \mathrm{Ali}, \mathrm{SI}, 422$.

${ }^{41}$ Ibid. p. 143.

${ }^{42}$ lbid. pp. 188-189.
} 
things in terms of material forms in order to explain adequately to those around him. ${ }^{43}$ This thought, however, is not new in Islam. Mu'tazili thinkers and the philosophers had already interpreted the concepts of heaven and hell allegorically.

'Ali accepts the Unitarian interpretation of historical Jesus. He sees Muhammad's role in history as being like that of Jesus. He says that, "the mind of Mohammed went through the same process of development which marked the religious consciousness of Jesus." ${ }^{44}$ In explaining the relation between the Creator and the Prophet of Islam, he believes that every man has the potentiality of developing his intellectual capacity, as did the Prophet of Islam. He says:

Probably in the infancy of his religious consciousness, Mohammed himself believed in some or other of the religions which floated around him. But with a wider awakening of the soul, a deeper communion with the Creator of the Universe, thoughts, which bore a material aspect at first, became spiritualized. The mind of the teacher progressed not only with the march of time and the development of his religious consciousness, but also with the progress of his disciples in apprehending spiritual conceptions. Hence in the later süras we observe a merging of material in the spiritual, of the body in the soul. ${ }^{45}$

This statement of 'Ali along with his assertion of Muhammad being the lawgiver is a challenge to the Islamic concept of divinity of the Qur'ân. This can be interpreted as Kenneth Cragg does, saying:

$\mathrm{He}$ ( $\mathrm{CAli}$ ) continually speaks of the contents of the Qur'ān as deriving from Muhammad's genius or wisdom or sagacity involving, that is the fullness of his mental powers... . ${ }^{46}$

'Ali appears to suggest that Muhammad had every command over what he was saying. But if this stand is considered to be right on the issue then a problem arises in understanding the Qurañic verse which says:

. .O Muhammad, tell them, it is not for me to make any alteration in it of my own accord. I follow only what is revealed to me. Indeed, if I disobey my Lord, I fear the chastisement of a dreadful Day (X:15).

${ }^{4}$ Ibid. pp. 198-200.

4 Ibid. p. 200.

45 Ibid. p. 200-201.

${ }^{46} \mathrm{~K}$. Cragg, Counsels in Contemporary Islam. (Edingurgh: Edinburgh University Press, 1965) p. 54. 
There are other similar verses in the Qur'ān (LXIX: 43-45). 'Ali's statement also implies that any person could reach the status of the Prophet through continued practice. But 'Ali tends to ignore that in Islamic history Muhammad's position is unique. He suggests that any person could reach to the state of Muhammad which the latter arrived at the time of receiving revelations from God. As for prophethood, the Quranic stand is that it has been the practice of God to send (arsala) His message to mankind through the office of prophets. 'Ali, on the contrary, takes the position that man reaches God and thus inspired. In 'Ali's thought this inspiration is the revelation. The Qur'an declares that God reveals inspiration and teaches wisdom of the Scripture according to His wish (11:151, LIII:10).

Amir 'Ali has similar problems in interpreting the existence of angels. $\mathrm{He}$ says:

Probably Mohammed, like Jesus and other teachers, believed in the existence of intermediate beings, celestial messengers from God to man. The modern disbelief in angels furnishes no reason for ridiculing the notion of our forefathers. Our belief, only is as much open to the name of superstition as their belief; ... what we, in modern times look upon as the principles of nature, they looked upon as angels. . . ${ }^{47}$

The Qurān refers to intermediate beings, between man and God in a few verses. It says, "Gabriel, who brings (revelations) to your heart by the will of God" (11:97). In another place the Quraan declares that he (the Prophet) was taught by a Mighty Power (LIII:5). There are other similar verses in the Quran. Qurānic commentators in general admit the literal interference of an intermediate being (Gabriel) in this process. ${ }^{48}$ In the philosophical interpretation of the Qur'an, however, these verses have not been interpreted literally. Interference of Gabriel has been identified with the concept of Active Intellect ( $A g l-i-f a^{c c} \bar{a} l$ ), and the Process of learning from God has been identified with the concept of annihilation (fana) by the philosophers. ${ }^{49}$ cAli does not deal with these philosophical concepts, but through his statement implies that he prefers similar interpretation. Throughout his work he admires the contribution of the philosophers in Islamic thought. Probably because of the opposi-

\footnotetext{
47 'Ali, SI, p. 64.

${ }^{48}$ Qasimi, Tafsir, Vol. XV, p. 5555/Qurtubi, al-Jami; Vol. XVII, p. 91/Qutb, Fi Zilal al Qur'an, Vol. XXV1I, p. 25./ Yusuf Ali, The Holy Qurän, p. 1443./ Zamakhshari, Haq al-Majid, Vol. II, pp. 1420-1421.
}

49 Ibn Arabi, Tafsir, Vol. I, p. 72 \& Vol. II, p. 555. Authenticity of this work has been challenged and it is said that it is a work of Kashani, and not of Ibn 'Arabi. (H. Landolt, "Der Briefwechsel Zwischen Kasani und Simnani, uber Wahdat al-Wugud," Der Islam. Vol. L, 1973). Our point, however, is that this concept existed among philosophers of Islam. 
tion of the traditional religious scholars against similar views of Sayyid Ahmad Khan, 'Ali was cautious in expressing his views.

Amir 'Ali, nevertheless, at one stage, claims that the Qur'an is the only miracle in Islam. ${ }^{50}$ This is a paradox in Ali's thought. He claims that the mind of the Prophet progressed with the passage of time, the Prophet's whole teaching is based on his sagacity and wisdom, when 'Ali rationalizes his thought. On the other hand he does not discuss in detail what he understands from his statement of the Qur'ann being the only miracle in Islam.

'Ali entirely denies the existence of any other miracle in Islam. He does not deal with the stories of Biblical prophets and their miracles as Sayyid Ahmad Khan does, ${ }^{51}$ but since miraculous activities were performed by Judaic prophets and it was commonly believed that prophets perform miracles, Muhammad was asked to do so. The Prophet of Islam spoke to "the inner

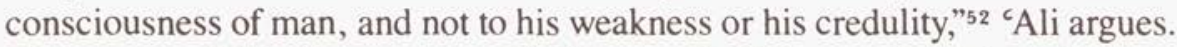
He launches Muir that even he (Muir) wanted Muhammad's claim to be supported by wonderworking. ${ }^{53}$

Amir 'Ali continues this same tendency of avoiding miraculous and superstitious stories about the Prophet's life. On the issue of the legends related of the Prophet's birth, he comments:

His birth, they say, was attended with signs and portents from which the nations of the earth could know that the Deliverer had appeared. The rationalistic historian smiles, the religious controversialist, who upon a priori reasoning, accepts without comment the accounts of the wise men following the star, scoffs at these marvels. To the critical student, whose heart is not devoid of sympathy with earlier modes of thought and who is not biased with pre-conceived notions, 'the portents and signs' which the Moslem says attended the birth of his Prophet are facts deserving of historical analysis. . . ${ }^{54}$

Amir 'Ali, in identifying himself with the last category and thus calling for historical analysis of such stories, avoids the whole issue. These stories are found in early literature on Sirah, for example in Ibn Hishām. 'Ali accuses Muir of giving 'animadversions' by following the account from Ibn Hishām's biography of the Prophet and scoffs at these as source materials. At the same time he defends Ibn Hishām, saying that "the work will continue to occupy

socAli, SI, p. 34.

${ }^{51}$ J.M.S. Baljon, The Reform and Religious Ideas of Syed Ahmad Khan. (Leiden, 1949) pp. 55-56.

s2 ‘Ali. SI, p. 33.

53 Ibid. p. 33 n.

54 Ibid. p. 9. 
the position of the most careful and trustworthy biographer of the Prophet."\$5 But, in fact, 'Ali himself also ignores many accounts given by Ibn Hishām as for example in case of the story regarding the Prophet's birth. He does not develop any formulae for critical scholarship in studying Islamic history as did Sayyid Ahmad Khan and Shibli Nu'mani. 'Ali accepted only those materials which conformed with his views. Interestingly enough, he appears totally to ignore the whole issue of the Prophet's night journey (XVII:1) in his later works. He deals with the issue only in his first work $A$ Critical Examination of the Life and Teachings of Mohammed published in 1873, where he interprets the night journey (me`raj) as a vision and refers to Muir for support. ${ }^{56}$

Two general trends are manifested in Amir 'Ali's works. Firstly, the defense of the Prophet's character as a person; and secondly the Prophet's career as a teacher, particularly his role in the intellectual development of human civilization. The reason for his defense of the Prophet in his continued interest in preserving his Muslim identity in a foreign environment. The environment he was living in was exclusively English. In such an environment he had to defend the Prophet to support his very existence in that society. At the same time he wanted his western educated co-religionists to retain their identity in the new environment.

Amir 'Ali describes the philosophers and scientists of Islam and the glory of Islamic civilization in page after page of his writings. He quotes European historians praising the development of Islamic civilization. It was Islam, he argues, which inspired Europe to rationalism, and "Avempace and Averros were the precursors of Decartes, Hobbes, and Locke." ${ }^{7} 7$ He mentions many other western thinkers who, according to 'Ali, learnt from Muslim scientists. He then goes on to his polemics against Christianity and claims that the European crusaders destroyed the cause of learning in the Muslim lands.

At this point we will not examine his claim that European scientists were influenced by Muslim scholars; rather what concerns us here is that why 'Ali took the initiative to show Islam's superiority to Christianity and former's similarity to the rational thought of the modern west. The reason behind this attitude lies in his motive to write on Islamic history. He wanted to tell his western readers that what had been known about Islam was distorted, and he wanted to encourage young Muslims that they could accept western liberal thought while still remaining under the banner of Islam. 'Ali criticizes the Abbasid caliph Mutawakkil and for his suppression of Mu'tazili thought, as well as Aḥmad bin Hanbal for his, as 'Ali puts it, anti-rational attitude. $\mathrm{He}$

${ }^{35}$ 'Ali, Critical Examination. preface, p. ix.

36 Ibid. 59.

37 'Ali, SI, 397. 
believes that it is because of this kind of attitude that Muslims of the modern age have fallen far behind their European contemporaries. He addresses young educated Muslims in the following manner:

For five centures Islam assisted in the free intellectual development of humanity, but a reactionary movement then set in, and all at once the whole stream of human thought was altered. The cultivators of science and philosophy were pronounced to be beyond the pale of Islam. Is it impossible for the Sunni Church to take a lesson from the Church of Rome? Is it impossible for her to expand similarity-to become many sided? There is nothing in Mohammed's teachings which prevents this. Islamic Protestantinism, in one of its phases, Mútazilims, - has already paved the way. Why should not the great Sunni Church shake off the old trammels and rise to a new life? ${ }^{58}$

It appears from 'Ali's call that he wanted to see a European style reformation in Muslim society. But his conceit was that he did not want to see this call coming from outside. His argument is that "reform comes from within and not from without." ${ }^{59}$ This appears to be another reason for his critical attitude towards the western works on Islam.

It appears from Amir 'Ali's interpretation of Islamic values that he was influenced by the English liberalism of late nineteenth century. He interpreted Islamic values in terms of English liberal values. He was widely read in various aspects of western civilization. Among English philosophers he appreciated the contributions of Jeremy Benthan, John Stuart Mill and Herbert Spencer to the development of the nineteenth century British liberal thought. ${ }^{60}$ Among those with whom Amir 'Ali had personal connections in England, some were Unitarians, some Positivists and some liberal Britons. Although most of the ideas which 'Ali maintained were present in Islamic history, an interesting issue here is why Ali chose only those ideas which were identical with some western ideas.

Among all religious movements in nineteenth century England, Unitarians had the best humanitarian feelings. ${ }^{61}$ They were the leaders of all liberal changes

\footnotetext{
38 Ibid. p. 454.

59 "Ali, "Islam and its Critics," Life and Works, p. 127.

60 "Ali, "Memoirs," p. 97.

${ }^{61}$ Raymond P. Holt, The Unitarian Contribution to Social Progress in England. (London: George Allan \& Unwin, 1938) p. 180.
} 
in England. ${ }^{62}$ Therefore it was natural for Ali to be influenced by humanitarian values of the Unitarians. In England he came into contact with Henry Chunning, nephew of the famous American Unitarian preacher. Therefore in his environment "Ali very well identified Islamic humanitarian values with the liberal ideas in England. He focused on the humanitarian provisions of Islam to convince his western audience that Islam recognized all human values long time ago. Particularly when dealing with the issues related to the Prophet's marriages, women's rights and slavery he stressed the humanitarian spirit of Islam. He had some practical problems in dealing with these issues. For example, although Islam recognized women's individuality and provides them with rights, yet it also accepts polygamy to a limited number. In the case of slavery also, the Prophet of Islam spoke for the well-being of slaves in humanitarian terms, but the institution existed and Muslims of later times took advantage from these provisions. All these issues became a target of western criticism of Islam. Therefore, 'Ali spoke for the spirit of the Islamic message in order to give a clear and adequate understanding of Islam to his western readers.

There is another issue in 'Ali's thought which is identical with Unitarian ideas. This is the interpretation of history of Christianity. Unitarians accuse St. Paul of corrupting the original simplicty of Christianity. ${ }^{63}$ Amir 'Ali also thinks that it is because of Paul that Christianity is corrupted today. ${ }^{64}$ Unitarians "are more impressed by and committed to the historical Jesus than by or to theological Christ." 65 This interpretation suits 'Ali's Muslim consciousness. Uniting his tone of criticism of modern Christianity with the Unitarians, 'Ali also takes an almost identical position. ${ }^{66}$

The use of reason in the scientific development and physicists' and biologists' view of human life shook all religious beliefs in nineteenth century Europe. Unitarian authors adopted an apologetic attitude toward the problem. ${ }^{67}$ As for 'Ali, we have already noted that he appreciated the contributions of philosophers such as Jeremy Benthan, John Stuart Mill and Herbert Spencer to the development of British liberal thought in the nineteenth century. Among them Bentham and Mill were Utilitarians; Spencer also contributed to Utilitarianism and was one of the most "argumentative and most discussed English thinkers of the late Victorian period." Although 'Ali liked their ideas

\footnotetext{
62 Ibid. pp. 13-28? passim.

${ }^{63} \mathrm{Ibid}$. p. 169.

${ }^{64} \mathrm{Ibid}$. p. 180

65 Valdeman Argow. Unitarian Universalism: Some Questions Answered. (Boston: Unitarian Universalist Association. n.d.) p. 6.

${ }_{66} \mathrm{Ali}$, SI, pp. 178-183.

${ }^{67} \mathrm{H}$. Malachlan. The Unitarian Movement in the Religious Life of England. (London: George Allan \& Unwin. 1934) pp. 127-149.
} 
about various aspects of human life, he probably could not accept their ethical theory that "an action is right if it achieves the greatest good of the greatest number of people, ${ }^{68}$ because of the interest of the Muslims in India. $\mathrm{He}$, therefore, was silent about the political aspect of their contribution. 'Ali, however, liked and could easily adopt their interpretation of various issues related to religious life.

"Theology is superceded by a positive stage of development," this theory of Comte dominated nineteenth century English thought. ${ }^{69}$ Auguste Comte's Religion of Humanity "encouraged reform tendencies in liberal Christian circles but stilmulated the rise of secular religious movements such as humanism." ${ }^{70}$ Comte's religious ideas were accepted and popularized in England by John Stuart Mill. Bentham and Spencer also believed in similar ideas. In 'Ali's interpretation of Islamic concepts we find existence of similar ideas. We have no evidence that 'Ali read Comte or that he interpreted Islamic concepts in the light of Comte's interpretation of the 'Religion of Humanity.' But, nevertheless, we can see the similarities between their ideas. We, however, know that when in England Ali was in close contact with the famous Positivist James Cotter Morison. ${ }^{71}$ Morison, having been influenced by Comte's ideas became active in London centering around John Stuart Mill. ${ }^{72}$ Although Mill was not known as a Positivist, he "chiefly through his acquaintance with the evolutionary ideas of Comte, . . . arrived at a sounder conclusion." ${ }^{33}$ Through his readings and personal acquaintance with British liberals and Positivists, it was quite possible for Ali to be influenced by Comte's ideas.

Amir 'Ali defines religion as follows:

... which places on a systematic basis the fundamental principles of morality, regulating social obligations and human duties which brings us nearer and nearer, by its compatibility with the highest development of intellect, to the All Perfect. . . . ${ }^{74}$

${ }^{68}$ Encyclopedia Britanica. 1970 ed. s.v. "Utilitarianism," by J.D.M.

${ }^{69}$ Basil Willey, Nineteenth Century Studies. (London: Chatte \& Williams, 1949) p. 182.

${ }^{70}$ Encyclopedia Britanica. 1970 ed. s.v. “Comte," by H.E. Bar.

"In his Memoirs (p. 49) he speaks about George Cotter Morrison, but no such person. author of a book on religion and another on Gibbon (as Ali refers) existed in London during his stay in England. However, another reference to this person as the father of Sir Theodore Morison confirms that his name was James Cotter Morison, and not George Cotter Morrison ( $E B, 1911$ ed.).

72 G.H. Busey, "The Reflection of Positivism in English Literature to 1880: the Positivism of Frederick Harrison" (abstract of a Ph.D. thesis, University of Illinois, 1924) p. 5.

${ }^{73}$ W.L. Blease, A Short History of English Liberalism. (London: T. Fisher \& Unwin, 1913) p. 238.

74 Ali, SI, p. 174. 
This understanding of religion, of existence of God, and man's relation with God are similar to the Positivists' synthesis of the religious consciousness. According to Comte, the father of Positivism, the definition of religion is, "that state of harmony peculiar to human life, in its collective as well as in its individual form, when all the parts of life are ordered in their natural relations to each other." ${ }^{75}$ Comte looks for the revelations of laws of nature to the intellect. ${ }^{76}$ According to his understanding, the progress of human civilization comes about as follows:

... the highest progress of man and society consists in a gradual increase of our mastery over all our defects of our moral nature. ${ }^{77}$

The basis of Comte's concepts are physics and biology. ${ }^{78}$ In the process of intellectual exercise "man reaches more and more fully to the state of real synthesis, as he more throughly recognizes the intellectual, and ultimately the moral, control exercised by the external order. . . " ${ }^{79}$ Comte again says:

This fundamental doctrine (External Order) of Positivism is not to be attributed in the full breadth of its meanings to any single thinker. It is the slow result of a vast process carried out in separate departments, which began with the first use of our intellectual powers, and which is only just completed in those who exhibit those powers in their highest form. ${ }^{80}$

About the concept of the order of nature Comte says:

Our fundamental conceptions about the Order of Nature are thus product of a collaboration between the world without and the mind within us. . nothing hypothesis duly confirmed by observation. ${ }^{81}$

Amir 'Ali argues, as Comte argues for Positivism, that Islam appeals to reason alone. The wave of scientific discoveries in the nineteenth century led both Ali and Comte to depend on intellect alone. 'Ali argues that there are verses in the Qur'an which appeal to the human intellect in order to convince man to recognize One Supreme Being. ${ }^{82}$ Comte also, through the use of reason in a gradual process, discovers the existence of an "Eternal Order" or a "Supreme Being." ${ }^{22}$ In this issue "Ali seems to ignore the fact that although

\footnotetext{
${ }^{75}$ Auguste Comte, System of Positive Polity. 4 vols. (New York: Burt Franklin, Originally published in London in 1875) p. II:8.

${ }^{76}$ Comte, A General View of Positivism. (New York: Robert Speller \& Sons. 1957) p. 355.

77 Ibid. p. 362.

${ }^{78}$ Comte, Positive Polity: p. II: 12.

${ }^{79}$ Ibid. p. 25.

${ }^{80}$ Comte, General View, p. 27.

${ }^{81}$ Comte, Positive Polity. p. II:25.

82 'Ali, SI, pp. 144 ff.

${ }^{82}{ }_{\text {(a) }}$ Comte, General View. p. 25.
} 
the Qur'an appeals to the human intellect, it claims to be the guidance only for the believers (11:3).

Comte recognizes, through the use of intellect, the necessity of submission to a Power without ${ }^{83}$ which, according to him, controls all human acts. ${ }^{84} \mathrm{He}$ feels the necessity of praying to his Power. Amir ${ }^{\mathrm{C}} \mathrm{Ali}$ advocates absolute submission to the Absolute Being and argues in favour of the rationality of Islamic prayers. ${ }^{85}$ But his rationalism fails to prove scientifically (in the light of late nineteenth century discoveries) the process of Divine knowledge to Muhammad.

In Comte's view, the theological synthesis depended exclusively on the affective nature of man, and it declined with the passage of time. He thinks that religions failed to satisfy the practical necessity of man. ${ }^{86} \mathrm{Amir}{ }^{\mathrm{C}} \mathrm{Ali}$ agrees with Comte about the practical function of religions in human life but identifies the fulfillment of these necessities e.g. the qualities of love, necessity of joint role of heart and intelligence, necessity of morality and social obligations in human life with Islam while Comte identifies them with his 'Religion of Humanity.' Comte observes about older religions that:

Positivists then may, more truly than theological believers of whatever creed, regard life as a continuous and earnest act of worship, worship which will elevate and purify our feelings, enlarge and enlighten our thoughts, ennoble and invigorate our actions. ${ }^{90}$

Ali as we have seen earlier agrees with Comte on the necessity of religion in human life but disagrees on the fulfillment of this necessity. He claims that although Christianity failed to fulfill this necessity, Islam satisfies these needs of mankind. He says:

The religion, therefore, which places on a systematic basis the fundamental principles of morality, regarding social obligations and human duties, which brings us nearer and nearer, by its compatibility with the highest development of intellect.... It is distinctive characteristic of Islam, as taught by Mohammed, that it combines within itself. . the reason and moral intuition of man. ${ }^{91}$

Comte claims Positivism to be the successor of Christianity and to surpass

\footnotetext{
${ }^{83}$ Comte, Positive Polity. p. II:11-12.

${ }^{84}$ Ibid. p. 16.

85 'Ali, SI, pp. 159 ff.

${ }^{86}$ Comte, General View. pp. $9 \mathrm{ff}$.

${ }^{87}$ Ibid. p. 16.

88 'Ali, SI, p. 181.

${ }^{89}$ Ibid.

${ }^{90}$ Comte, General View, p. 365.

91 'Ali, SI, 174.
} 
it. ${ }^{92}$ Similarly Amir 'Ali argues that Islam is the developed form of all Scriptural religions, ${ }^{92}$ and supports his argument by pointing to its successful uplifting of "lower races to a higher level of social morality." ${ }^{93} \mathrm{He}$ argues that Christianity remained an 'incomplete religion' because Christ did not live long, and it was left to Muhammad to complete his mission. ${ }^{94}$

Both 'Ali and Comte were against the creeds and stagnation of thought in the middle ages. ${ }^{95}$ Moreover, according to them, character of the society was too military and aristocratic in the middle ages. Comte found the solution of the problems of the middle ages in the sub-ordination of politics to morals. ${ }^{96}$ 'Ali found the solution of the same problems in the revival of the spirit of the message propagated by the Prophet of Islam. Comte wanted a priesthood of pholosophers in order to create a just society based on moral values, ${ }^{97}$ and 'Ali appealed to the educated Indian Muslims to shoulder the responsibility of the Muslim community. ${ }^{98}$

In comparing Amir 'Ali's thought with that of Comte, one must keep in mind that we have no proof that 'Ali read Comte. But since their thoughts are similar we can say that 'Ali was influenced by Comte; if not directly after reading Comte, then by similar ideas in late nineteenth century British liberal thought on which Comte had a permanent impact. There is also another problem arising from the comparison between Comte and 'Ali, namely, whether we could call 'Ali a Positivist. In our view, the answer is negative, because of the basic difference between them. Comte, through his positive thought, reached to the conclusion that through the continued practice of positive thinking a just society could be established. This is a continued process, according to Comte. As for 'Ali, everything positive is already there in Islamic teachings, and if one practises these teachings, he could achieve the goal of establishing a just society.

Amir 'Ali primarily spoke to the westerners in western terms. His work was a part of a Christian-Muslim dialogue in the modern age. He tried to translate Islamic thought into the language of nineteenth century British society. Probably that was the reason why he identified the humanistic qualities of Islam in terms of the British values of those days. Since Comte was one of those philosophers who made a decided impact on the nineteenth century European thought, 'Ali spoke to his western audience in the same terms.

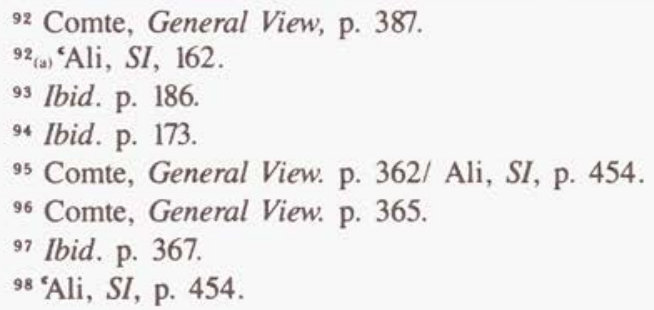




\section{III}

Amir 'Ali's writings signify another major development in modern Islamic thought. This aspect of his contribution is his endeavour to bring Sunni and Shi' ah Muslims closer to each other. Efforts in this way began in the Indian sphere of Islam in Shäh Wali Allah's thought. ${ }^{99}$ This trend continued in India, and when Amir 'Ali appeared in the field, he found already a 'Shi'ahSunni patch up.' He gives credit for this to western rivalry towards Muslims. ${ }^{100}$ He considers this 'patch up' a part of practical politics. ${ }^{101}$ In his writings on Islamic history, 'Ali glorifies every hero of Islam irrespective of their background, He gives full credit to the first two caliphs for their contribution to the development of the Islamic community. He, however, accuses the Prophet's companions of hiding traditions supporting 'Ali's (the fourth caliph) succession as the leader of the community. ${ }^{102}$

The most interesting part of 'Ali's role in history is his stand on the defense of the Ottoman Caliphate against the Kemalists in Turkey. Historically the Twelver Shi'ahs have always opposed the institution of caliphate; but unlike the traditional stand of his school, 'Ali's opposed the abolition of the caliphate. The traditional Ottoman regime in Turkey became weak and corrupt by the beginning of the twentieth century. There were various reforms in Turkey. In spite of his advocacy for reform, 'Ali's support for the caliphate suggests his emotional attachment to the age-old institution. He propably wanted to see a traditional British type monarchy in the Muslim world.

Another aspect of 'Ali's writings is manifested through his contribution to the development of political consciousness of the Indian Mulsims. He not only spoke for the rights of Indian Muslims, but spoke for the Muslims of other countries also. He endeavoured to influence the British foreign policy towards Mulsim countries. He, at times, spoke for Indians in general too. He started writing on the political problems of India as an Indian, ${ }^{103}$ but soon he identified himself as an Indian Muslim. It appears from his writings that he maintained this identity throughout the rest of his life. Because of his pro-Muslim attitude he was accused of being a separatist, but 'Ali denied this allegation strongly. ${ }^{104} \mathrm{He}$ at the same time admitted that Hindu-Muslim fusion in one country was impossible. ${ }^{105} \mathrm{He}$ wanted the permanence of British

${ }^{99}$ I.H. Qureshi, The Muslim Community of the Indo-Pakistan Sub-continent. (The Hague: Mouton \& Co. 1962) pp. 178-182.

100 'Ali, Mahommedan Law. 2 vol. (Calcutta: Thacker, Spink and Co. 1908) p. I:3.

101 'Ali. The Caliphate." p. 424.

102 'Ali, Mahommedan Law. p. I:3.

103 "Ali, "Some Indian Suggestions for India," Life and Work. pp. 3-22.

104 'Ali, "The Mohammedans of India and their Place in the empire," Life and Work. p. 383.

105 "Ali, "The Mohammedans of India and their Place in the empire," Life and Work. p. 383. 
rule in India. He considered British rule was in the interest of the Muslims. He never thought of a separate sovereign Muslim state, but at the same time he wanted some type of protection of Mulsim rights in the Indian sub-continent. He could not accept Utilitarian theory of "an action is right if it achieves the greatest good of the greatest number of people" in this issue. He saw such protection as possible only through the continuation of British rule in India. Therefore, he encouraged Indian Muslims to acquire knowledge of the English language and civilization in order to gain British sympathy.

Amir 'Ali severely criticised British policy in the Middle East. He spoke for the Turkish cause against its European enemies. He appealed to British public opinion, to their consciousness in the name of liberalism to support in the latter's war against Italy in the early twentieth century, not only because Turkey's cause was just but also because England was the greatest Muslim power in the world at that time. ${ }^{106} \mathrm{He}$ was not willing to accept Turkish or Libyan actions against Italy as Muslim atrocities, and in the same way he appealed to the Britons not to accept Italian atrocities as Christian atroticities. Rather, according to him, both actions should be opposed because they were unjust. He complains, "were even a fraction of these acts (Italian atrocities in Libya) committed by the Turks, there would have been a hawl of indignation throughout the length and breadth of Great Britain." ${ }^{107}$ Apparently frustrated 'Ali asks, "Will not the Christian men and women of England, who cherish the noble ideas of their faith, raise their voice against the barbarism of bygone days?"108

'Ali criticises western civilization as being 'white' and 'racist' when complaining against the treatment met by Indians in Africa and Canada. ${ }^{109}$ Interestingly enough, although he always spoke for the Muslim cause, in this issue he spoke only for the Indians in general, and not for the Blacks, even if the 'Black Muslims' also faced similar problems in British colonies.

\section{IV}

Sayyid Amir 'Ali was born and brought up in the beginning of the transitional period of Indian Muslim society. It was a transition from a traditional society to a modern one, in the sense of adopting western views of life and technological development. The Indian Muslims had just realized that their period of rule was over and their very existence was being threatened in the new circumstances.

\footnotetext{
106 'Ali, "The Mohammedans of India." p. 384.

107 "Ali, "Italy and Turkey," Life and Work, p. 365.

108 Ibid. p. 357.

109 Ali, "Anomalies of Civilization-A Peril to India," Life and Work. pp. 290-291.
} 
Birth of civilization and its development is a type of 'challenge and response' game. Toynbee says about the origin of civilization that, “. . though there may have been some degree of physical challenge to stimulate them (civilizations) too, the principal and essential challenge was a human challenge arising out of their relationship to the society to which they were affiliated."110 Amir 'Ali's contribution to history appears to be an example proving Toynbee's theory.

The understanding of Islam in the West, particularly among the English, did not disturb the Muslim consciousness in India until the political dominance of the British became clear to them. Only after the severe suppression of the 'Uprising' of $1857,{ }^{\prime \prime \prime}$ Indian Muslims realized that the depiction of Islam in the English language mattered to them. They tolerated the political and economic dominance of the British, but they did not accept the realigious dominance. They considered the challenge as a direct threat to their identity. Christian missionary activities had only added to their worry.

Amir 'Ali was one of those few Muslims who were exposed to the literature on Islam in the English language. The Muslim reaction to English missionary activities in India in the form of politics and scholarly writings began with Sayyid Ahmad Khan's activities. The literary activities of Sayyid Ahmad Khan and his close associates were more or less confined to the Indian languages. The Muslim reaction to the depiction of Islam in the English language received a forceful expression in the writings of Amir 'Ali.

'Ali admits that he undertook the task of writing about the life of the Prophet of Islam in order to refute 'every false theory' and 'apocryphal story' stated by western historians, with his object being "to embody the principal features of the life and teachings of the Arabian Prophet in a popular shape; to disabuse the minds of many readers of false impressions and false prejudices; to try and prove that Islam has been a real blessing to mankind; that it also has helped to elevate Humanity...."112 If the term 'apologetics' is defined as "the Christian defense against attack by non-Christians," 113 then Amir 'Ali's attitude can rightly be called an apologetic for Islam. He reacts against what he calls some 'false theories.' His first publication, which he wrote when he was in England for higher studies, came out in 1873. 'Ali in his A Critical Examination of the Life and Teachings of Mohammed answers to those questions about the life and teachings of the Prophet of Islam which he considers as false notions.

110 Arnold Toynbee, A Study of History: Abridgement edition. (London: Oxford University Press, 1960) p. 77.

III Famous 'Uprising' against the British is normally termed as the 'War of Independence' by Indo-Pakistani historians and 'Mutiny' by the Britishers.

112 'Ali, Critical Examination. preface, p. viii.

${ }^{113}$ Encyclopedia of Religion and Ethics. S.v. "Apologetics" by T. W. Crafer. 
Amir 'Ali changed his attitude, to a certain extent, when he enlarged his first book in 1891, giving it to the form of formal history in a work entitled The Spirit of Islam. His attitude towards Christianity in his first work is that it was not only Christianity which contributed to the development of humanity, but that Islam also helped to elevate men. Islam and Christianity received equal honour. But in his later works he focuses on Islam's superiority over Christianity. His attitude towards Sir William Muir, against whom he basically reacts, also changes during this period. In 'Ali's first book he gives credit to Muir for possessing a 'real earnestness,' but in the Spirit of Islam he holds Muir to be an enemy of Islam. ${ }^{114}$ In the Critical Examination Ali frequently refers to Muir and appeals to his readers to judge between his presentation and Muir's presentation of history where he differs with the latter. ${ }^{115}$ But in the later enlarged edition of his work he is more confident of himself and avoids this tendency totally. In his first book he refers to Muir for support in those matters which the latter considered to be the positive apsect of Islam. But in the later edition his attitude towards Muir is absolutely inimical. Even he refers to a quality of the Prophet mentioned by Muir, he qualifies the statement by saying that Muhammad was such a great personality that an enemy such as Muir also had to accept it. ${ }^{116}$

Now the interesting question is why Amir 'Ali's critical attitude towards Christianity and Muir increased with the passage of time. The reason, in our view, was the environment in which 'Ali lived. It was pre-dominantly English and thus Christian. He was well-read about the English culture and civilization and was influenced by the British liberal ideas when in England in contact with a few British intellectuals. About his first experience in practical life as a lawyer in the Calcutta High Court, he says:

I expected no backing and received none. The English solicitors looked upon me as an interloper; the Hindus frankly disliked me; whilst the Muslims considered me a renegade because of the English method of life I had acquired. ${ }^{117}$

He apparently chose to live in an English atmosphere willingly where most of the Englishmen considered him an 'interloper.' It is true that in his personal life he married an English woman of 'some position. ${ }^{118}$ and he was greeted by a few English liberals, but probably most of the Englishmen he came across were not liberal in their attitude. 'Ali, on his part, was always conscious about

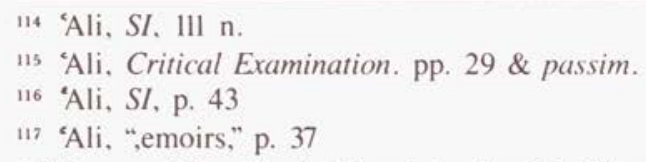

${ }_{118}$ Thomus Wise, "Amir Ali and the English Views of Islam" The Journal of the University of Peshawar. (no. 5, 1956) p. 68. 
his Muslim identity. Therefore he must have encountered a number of questions about Islam and the Prophet of Islam in that society. Such questions may well have been supported by Muir's Life of Mahomet, as that work was often taken to be the authority on Islam in the English language. His continuing effort to preserve self-identity in a foreign environment became a challenge to his existence in that society. It appears that in order to justify himself in that environment he began to write on the subject. Since he had to face increasing opposition to his views from the supporters of Muir, his attitude towards Muir and his Christian supporters changed over time.

Amir 'Ali's environment influenced him in another major aspect of his writings, that being the question of reason and humanity in religion in general and in Islam in particular. The development of the physical sciences in the eighteenth and nineteenth centuries caused discussion on this problem among European philosophers and theologians. ${ }^{119}$ While in England Amir 'Ali was influenced, not by apologetic Christian theologians but by a number of British intellectuals of liberal ideas. The new discoveries in physics and biology had undoubtedly British liberal thought in the nineteenth century. Amir 'Ali was apparently influenced by positivist philosophy of Auguste Comte. Comte thought that the time for theology was over and the time for positive philosophy had arrived. Comte criticised Christianity as well as theology in general and gave foundation to Positivism as a new religion in order to accomodate the qualities of humanity and to encourage the development of physical sciences. According to him, the time for Christian theology was over and the Religion of Humanity, i.e., Positivism, had replaced it. Amir 'Ali, on his part, apparently adapted the ideas of Comte by identifying the human and rational qualities of Positivism with Islam. Comte argues that Positivism is the developed form of Christianity, and 'Ali argues that it is Islam which has accommodated rationalism and encourages the development of physical science.

The question of 'Ali's audience is a much debated issue among scholars. He himself claimed to address both western victims of 'false ideas' on Islam, and Indian educated Muslims. Yet he claimed to have the Indian Muslims primarily in mind. Fazlur Rahman and W.C. Smith accept this view. ${ }^{120}$ Amir 'Ali's attitude appears to have been a developed form in Islamic development in India. Sayyid Ahmad Khan, at his time was concerned that young Muslims were rejecting modernity and thus could not cope with their European contemporaries, while Amir 'Ali, on the contrary, was concerned that young western educated Muslims might reject their traditional faith and thus their identity. Aziz Ahmad, for his part, thinks that 'Ali's re-statement of Islamic

${ }^{119}$ Encyclopedia of Religion and Ethics. s.v. “Apologetics," p. 613.

${ }^{120}$ R. Rahman, "Muslim Modernism in the Indo-Pakistan Sub-continent" Bulletin of the SOAS.

Vo. XXI, Part-1, 1958, p. 87/Smith, p. 49. 
history was aimed at his western audience, where it made a considerable

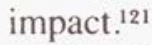

We will discuss the impact of 'Ali's works below. At this point, our endeavour is to determine who he was primarily addressing. In most of his works he spent page after page refuting the views of western historians and glorifying Islamic history, in comparison with only a few pages criticising those facts of Islamic history with which he did not agree. For example, he does not agree with the views of Ahmad Ibn Hanbal, the famous jurist and theologian of Islam, nor does he like the anti-Mu'tazili stand of Abbasid caliph Mutawakkil. In principle one should critically examine the views of the two rival groups, and in order to provoke thought among his probable followers, should try to convince them that the proper way to approach matters is not the conservative way of suppressing thought as Mutawakkil did, but rather, since Islam encourages reason, that one should encourage free thought. Instead of doing this he spent more energy attacking Christianity and legitimizing the actions of Muslim rulers and jurists. This attitude of 'Ali illustrates his sense of inferiority with respect to his western audience. It appears that he was simply addressing the people around him legitimizing his existence in that society, and asserting that Muslim history at any rate is not inferior to Christian history. On the contrary, he sees it as superior in many respects. As for the people around him, he always lived in an English environment irrespective of his stay in India or in England.

From his claim about the superiority of Islam over Christianity, it appears that he wanted to convince his liberal friends that Islam accommodates difference of opinion and that there are examples in Inslamic history in this respect. His critical attitude towards Christianity appears to have been directed against those who considered 'Ali an interloper in the English environment. This tendency in 'Ali's writings suggests that his primary concern was the westerners around him.

'Ali used English as his medium of expression. Had he had young Indian Muslims in mind, he should have written in an Indian language since he always claimed that Indian Muslims had one cultural language. ${ }^{122}$ This could have inspired both western educated Muslims as well as those educated in Islamic languages. Another aspect of 'Ali's writings indicates that the type of people he was writing for, that being his use of terms in expressing his views. He uses terms such as 'Church of Mohammed,' 'Sunni Church,' 'Saracens', 'Lower Race,' 'Apostoletic,' etc. These are absolutely western terms, and in most cases Muslims were not familiar with these terms. 'Ali justifies the use of terms saying that: 
I use the word 'Church' to convey the meaning which no other word can express - a consolidated body of doctrines expanded to age which have become part and parcel of the religions of the religious life of the nations. . . ${ }^{123}$

This indicates that 'Ali was trying primarily to convey his message to a western audience. Most of the books and articles written by 'Ali were published in England. This also indicates that his primary concern was the westerner's understanding of Islam. But this does not mean that he had no concern for Indian Muslims. This concern, however, was of secondary nature.

Amir 'Ali's approach to Islamic history manifests that he had a particular reason behind writing about Islamic history. He wanted Muslims to recapture the Mu'tazili thought of early Islam in order to face the challenge of the west. He particularly stressed the humanistic values of Islam. The focus on Islam as the religion of nature also dominates his thought. He pointed to the material, philosophical and moral development caused by the Islamic message. He often defended or sometimes kept quiet when those developments were hampered by the Muslim rulers and jurists. This method of history-writing has been criticised by his critics. 'Ali himself questions Muir's methodology and accuses him of being prejudiced and of writing history in order to prove some of his pet theories. ${ }^{124}$ It was in order to refute those theories that Amir 'Ali wrote, and apparently he also had his own theories to prove. Therefore, from the methodological point of view, there is no fundamental difference between them. The main difference between 'Ali and Muir is that Muir had a pre-conceived notion of Islam as a religion inferior to Christianity, and thus felt that Christian missionaries working among Muslims should be equipped with a work that can provide with confidence in this respect. 'Ali had a preconceived idea that Islam is superior to Christianity and is based only on science and reason, and so Muslims should feel confident about it. 'Ali was primarily a lawyer, not a historian. He wrote on history for certain reasons. This brought "more good than harm to the reputation of Amir "Ali and Islam" in England. ${ }^{125}$ His interpretation of Islamic teachings and his focus on particular events in Islamic history created a sense of self-reliance, pride and confidence among educated young Muslims in India. This was a developed stage for the Indian Muslims. Most western educated Indian Muslims, like Amir 'Ali, came in contact with the English environment either on a personal or professional level. Because of their pride in former Muslim political and economic dominance, they became victims of an inferiority complex.

\footnotetext{
123 "Ali, "The Caliphate," p. 388.

124 “Ali, Critical Examination. preface, p. vi.

125 Wise, p. 69.
} 
Although they admired western values, psychologically they could neither abandon their patriarchial faith nor accept the Christian missionary propaganda against Islam. Sayyid Ahmad Khan's activities acquainted them with western civilization and development, but could not provide them with a sense of pride. On the contrary, his apologetic works on Islam increased their sense of inferiority. While western educated Indian Muslims were in this state of mind, Amir 'Ali appeared armed not only with defensive, but an offensive attitude. 'Ali's polemics along with his official position in the British Indian government provided this new generation with a new confidence. This new confidence encouraged Indian Muslims to be liberal like an English gentleman, and at the same time to be proud of their identity. W.C. Smith observes that 'Ali's monumental work The Spitit of Islam represents this whole trend of Indian Muslim society. ${ }^{126}$ Smith describes these young Muslims as:

A young Muslim fashionably dressed, sits with his friends in the Lahore Coffee House and talks, in English, of Marx or tennis. He has perhaps never studied the Qurän . . yet intensly conscious about being a Muslim, he insists that he and his co-religionists in India are a nation, and he is, he says, ready to fight to establish for them a free country. ${ }^{127}$

This new generation of young Muslims were so confident about their 'modern' attitude, influenced by English liberalism, along with their Muslim identity, that if anyone asked them about the apparent contradiction between Islam and their liberal nationalistic spirit, they at once would answer "well, didn't you read The Spirit of Islam of Amir 'Ali?" However, the contradictions in 'Ali's interpretation were reflected in the views and behaviour of this new generation of Muslims.

There is another reason for Amir 'Ali having emerged as the hero of new young Muslim generation in India who represented the upper and upper middle class landed aristocracy. 'Ali's success in presenting the Muslim cause to the British authorities made him popular among these people. 'Ali identified himself a 'loyal' Indian Muslim and fought for Indian Muslim rights throughout his life. Muslims, who had suffered from their loss of political and economic power found a ray of hope in the brilliant career of Amir 'Ali both in his private and public life. He was successful in his career in the British Indian judicial service and went on to the highest position then available to an Indian. As a successful lawyer he pleaded for the Muslim cause not only for India but for the whole Muslim world. He realized that there was a religious prejudice in the west against Islam and Muslims because of some false theories.

126 W.C. Smith, Islam in Modern History. (New York: New American Library, 1957) p. 62.

${ }^{127}$ Smith, Modern Islam. p. 8. 
$\mathrm{He}$ apparently was worried about the political implications of this religious prejudice. Therefore he advocated the inclusion of some Muslim countries in the League of Nations, appealed for support to the victims of the Balkan and Turko-Italian wars, and criticized the British attitude towards Turkey after the First World War. His normal defensive tone sometimes changed to an offensive attitude. So he attacked the western civilization, and European attitude by saying:

The bogey of Pan Islamism maliciously held up to the imagination of European people's as a militant force bent on a struggle of strength with Christendom, was a mischievous invention for the purpose of justifying European aggression. ${ }^{128}$

Amir 'Ali, however, did not succeed in convincing British public opinion of the need for a positive attitude toward Muslims other than Indians. He failed to make an impact on the formation of the British foreign policy, although he considered Britain as the biggest Muslim power in the world at that time. Moreover, his random criticism of Christianity and western civilization, probably had an adverse effect on his western audience. He certainly received help from the British people in his social activities, for example in running the British Red Crescent Society, but the help was apparently confined to social activities only.

In India 'Ali wanted to see the co-existence of the Hindus and the Muslims in one society.129 But he did not see the protection of Muslim rights to lie in an independent India. Therefore, to him the permanence of British rule in India was essential, and it was in the interest of the Muslims..$^{130}$

Amir 'Ali's attitude towards the British and towards the future of India added to his popularity among educated young Muslims. Probably that was the reason that Muhammad Ali Jinnah, the founder of Pakistan, wanted Amir 'Ali to become the president of All India Congress, when the former was trying to bring the Hindus and the Muslims on one platform. ${ }^{131}$ Amir 'Ali's contribution to the Muslim nationalistic spirit apparently existed in Jinnah's mind even after the creation of Pakistan. It is manifested in Jinnah's statement that, “ . . . (in Pakistan) in course of time Hindus would cease to be Hindus and Muslims would cease to be Muslims, not in the religious sense, because that is the personal faith of each individual, but in the political sense as citizens of the state." ${ }^{132}$ The poet philosopher Muhammad Iqbal when at Cambridge for higher

\footnotetext{
128 'Ali, "Additional Chapter on Moslem Feelings," Life and Work. p. 361.

129 'Ali, "The Unrest in India-Its Meaning." Life and Work. p. 251.

130 "Ali, "Presidential Address to the Muslim League Delhi Session" Life and Work. p. 330.

131 “Ali, “Memoirs," p. 92.

${ }^{132}$ M.A. Jinnah, Quaid-i-Azam Speaks. (Karachi: Pak Publicity, n.d.) p. II.
} 
studies, was in close contact with Amir 'Ali. He apparently prepared the index for the Spirit of Islam of Amir 'Ali.

'Ali's works particularly The Spirit of Islam, a flagbearer of Muslim liberalism, as W.C. Smith calls it, had an impact in other Muslim countries outside India. The book has been translated into Arabic, Indonesian, Turkish and Urdu and is widely quoted by later Muslim scholars. The book made a considerable impact in the west also. One western convert to Islam writes:

The book which most impressed me in my Islamic studies was The Spirit of Islam by Syed Ameer Ali, although this book is not without criticism in the Muslim world with regard to many customs and attitudes which the author wished to see reformed. It does, however, put before Muslims and the world as a whole, the true inspiring grandeur of the faith of Islam which it should surely be the duty of every Muslim to attempt to bring down to the realm of practical life. This undoubtedly is a book which all Muslim students should endeavour to study. ${ }^{134}$

We noted earlier that 'Ali's offensive against Christianity had an adverse effect on British public opinion and consequently he failed to win their support for Muslims outside India. There was another adverse effect of 'Ali's works, and this was on educated Indian Muslims. He always stressed the achievements of the Muslim rulers and intellectuals. This over emphasis on the glorious parts of Islamic history created a sense of "everything among Muslims is good, 'Muslim history is the best history mankind has ever produced.' This attitude discouraged young educated Muslims from studying their history critically, which in turn exerted an adverse effect on their orientation.

Amir 'Ali did not deal with theological issues directly. But what he said in order to rationalize the progress of revelation should have been sufficient to provoke the 'Ulama to react. Why they did not, is an interesting question to consider. Probably the type of 'Ulamā who reacted against Sayyid Ahmad Khan were not in a position to understand 'Ali's writing in English. An American convert Maryam Jamilah, at a later date, observes about 'Ali's works that:

If the 'Ulamä had been alive to their duty instead of sleeping, the contents of this book (The Spirit of Islam) should have been denounced as heretical. ${ }^{135}$

${ }^{133}$ M.F. Citrine, The Islamic Review. (Jan.-Mar. 1963) p. 17.

${ }^{134}$ M.F. Citrine. The Islamic Review. (Jan.-Mar. 1963) p. 17.

${ }^{135}$ M. Jamilah, Islam and Modernism. (Lahore: Muhammad Yusuf Khan. 1968) p. 56. 
Still, in the development of the Indian Muslim community Amir 'Ali's works have played a remarkable role. He succeeded in motivating young western educated Muslims to retain their identity amidst western oriented societies. His stress on self-reliance motivated Muslim nationalistic feelings. In politics, 'Ali was interested in the well-being of the fellow Indian Muslims. There also he earned respect of Indian Muslims. Thus the products of Aligarh Movement in India most often derived their intellectual orientation from Amir 'Ali's works. 